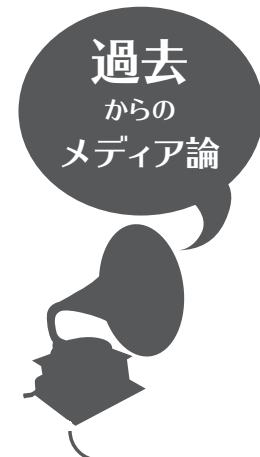

Seeing current media retrospectively

\title{
職務発明制度改革 技術者倫理からの考察
}

大谷卓史 (吉備国際大学アニメーション文化学部) 情報管理５7(8), 588-590, doi: 10.1241/johokanri.57.588 (http://dx.doi.org/10.1241/johokanri.57.588)

2014年9月特許庁の有識者会議で，企業が従業員に 報酬を支払う制度があれば，企業の従業員が発明の 特許を受ける権利を企業に帰属させることとする改 正案を提出する方針が決まった，と報道された注1）。

現行特許法35条は，企業の従業員が職務上発明し た「職務発明」について，原始的に従業員に特許を受 ける権利が帰属する（つまり，従業員が発明者である） ものの，同時に使用者（法人または国など）は通常 実施権を有する旨を規定している(同1項)。この場合， 報酬に関する定めはない。そして，契約や勤務規則 などで，使用者に特許を受ける権利を承継させたり， その専用実施権を与えたりした場合などには，相当 の対価（補償金）の支払を受ける権利が従業者には ある(同3項)。これを権利主義という注2)，1）。

現行法の「相当の対価」の額をめぐっては，1990 年代から使用者と従業員との間で法的紛争があっ た。発明者たる従業員が十分な対価を得ていないと して訴えを起こし，裁判所が勤務規則等で事前に定 められた額だとしても客観的にみて「相当の対価」と いえなければ不足分を請求できるという判決が相次 いだ（代表的な裁判例は，青色発光ダイオードの発 明者への対価をめぐる訴訟注3)，およびオリンパス光 学工業の技術者が発明の補(償金を求めた事件注4) 。こ れらに対する使用者の反発が募る一方，使用者と従 業員との間では力関係に不均衡があるから，従業員 保護が重要という議論も行われた3)。

その結果，事前の「定め」が不合理でない限りは「定 め」に従つて対価を支払い，「定め」がない場合には 客観的に相当と考えられる対価の額の支払が求めら
れるという改正が行われた（平成16年改正，特許法 35条4項および5項) 3)。

そもそもわが国の特許法の歴史をさかのぼると， 明治42年特許法においては，職務上又は契約上なし た発明の特許を受ける権利は，原則としてその職務 を執行させた者に帰属する，とされた（明治42年法3 条)。大正10年特許法で，職務発明が定められ，発明 者は従業員であり，使用者はこの権利を承継もしく は専用実施できるという規定が定められた（大正10 年法14条) 1)。

大正10年法14条がどの国の特許法をモデルとした かは定かではないものの，わが国の産業の発達と技 術の重要性の増大を背景にして，大正デモクラシー の影響から従業員である技術者の権利が認識された ものという見解もある4)。

技術者の研究開発へと向かう動機付けはお金だとい う考えが，十分な報酬を支払えば，従業員の発明は使 用者などのものになるという改正提案の背景にはある ように思われる。

使用者の設備を利用し，使用者の多大な投資が発 明行為にあって，さらに，一緒に使用者のもとで働 く仲間との共同作業があるのだから，技術者1人だけ の手柄にして，使用者やその他，直接・間接に貢献 があった者に見返りがないのはおかしいという議論 も一見説得力はある注5)。

ただ，使用者などの投資への見返りをどうするか という前者の課題については，使用者が専用実施権 を承継する条件をより安定的にすればよいだけであ る。一方，直接・間接に発明に貢献したその他の人々 
にどう報いるかという後者の問題については，それ こそ直接貢献があった人々には賞与や給与のアップ という形で報いればよいし，間接的に貢献した人び とには会社の業績アップでやはり賞与や給与の向上 がもたらされるようにすればよい。

もちろん知財を管理する立場からみると，発明者 が従業員でその専用実施権が使用者などとなると確 かにややこしい。しかし，これもICT Information and Communication Technology，情報通信技術）の 活用などで問題を整理・解決すべきことではないだ ろうか。

特許権などの産業財産権も，著作権と同様に人格 性（personality）を基礎に有する可能性がある。自 分自身が発明者であると認められたいという名誉動 機や，自分自身の才能や努力に対する誇りも技術者 にはあるのではないか5)。つまり，特許をはじめとす
る知的財産は，自分の人格の産物・人格の誇るべき 一部として，技術者は考えているかもしれない。 知的財産が発明者・著作者の人格の延長であるか ら保護すべきという思想は，倫理学においては，人 格性基礎的正当化またはへ一ゲル的正当化と呼ばれ ることがある6) 8)。

また，技術者は専門職であるという主張があるも のの，ほかの専門職とは違って，一般的に被雇用者 であるため，独立性が弱く，本来の専門職として活 躍する余地が少ないという議論がある5)。特許の発明 者となることは，使用者との間に一定の緊張関係を つくり，専門職としての（一定程度の）独立性を保 障するよすがだったかもしれない。

今回の改正提案は，技術者の専門職としての独立 性をさらに下げ，技術者倫理など思いがけないとこ ろに影響を与えるのではないかという懸念もある注6)。

\section{本文の注}

注1）「社員の発明，特許は企業に 産業界が報酬ルールに理解」『日本経済新聞』2014年9月4日 http:// www.nikkei.com/article/DGXLASFS03H1X_TO0C14A9EE8000/2014年9月13日。なお，この報道に先立 ち，従業員の発明は無条件に企業に帰属するとの他紙の報道もあったが，これは誤報であった。

注2）現行特許法における職務発明制度は，インセンティブ論からみると奇妙であるという指摘もある2。 しかし，さまざまな利益のバランスから社会的利益の最大化を図る規則功利主義の立場を採用すれば， 使用者や法人などの投資も同時に考慮する職務発明の「特別扱い」も正当化が可能かもしれない。こ の点についても，稿をあらためて論じたい。

注3）東京高決 平17.1.11 平16（ネ）第962号 判時1879.141

注4）最三小判 平15.4.22 平13（受）第1256号 民集57.7.477

注5）前出注1）の記事参照。

注6) フランス・イギリスでは，今回の改正提案と同様の法制度を採用している。両国では技術者倫理をめ ぐって具体的な問題が生じているかは明らかではないが，両国の技術者倫理の状況には，他国と比較 して興味深い特徵がある。

\section{参考文献}

1) 特許庁. “職務発明制度の概要". http://www.jpo.go.jp/seido/shokumu/shokumu.htm, (accessed 2014-0913).

2) 永野周志. 特許制度の存在理由と職務発明制度 : 特許法35条批判 (3). パテント. 2004, vol. 56, no. 6, p. 65-75. 
3）中山信弘編著. 知的財産政策. 財団法人経済産業調査会, 2011, p. 305-306，(通商産業政策史 1980-2000 第11巻).

4) 中山信弘編著. 注解特許法 上. 第3版, 青林書院, 2000, p. 336.

5）大谷卓史. “4章 技術者と倫理”. 知識ベ一ス知識の森. 電子情報通信学会, 2012. http://www.ieice-hbkb.org/ files/S1/S1gun_07hen_04.pdf, (accessed 2014-09-13).

6) Moore, Adam D. Personality-Based, Rule-Utilitarian, and Lockean Justifications of Intellectual Property. Wiley, 2008, p. 105-130. (Kenneth Einar Himma and Herman T. Tavani eds. The Handbook of Information and Computer Ethics).

7) Hughes, Justin. The Philosophy of Intellectual Property. Georgetown Law Journal. 1988, vol. 77, p. 287366.

8) 大谷卓史. 著作権の哲学 : 著作権の倫理学的正当化とその知的財産権政策への含意. 吉備国際大学研究紀 要. 2011, no. 21, p. 1-24. 